\title{
Growth-promoting thermophilic microorganisms in self-heating pasteurized substrate improve Agaricus bisporus mycelial growth
}

\author{
Microorganismos termófilos promotores del crecimiento en un sustrato \\ pasteurizado por autocalentamiento mejoran el crecimiento micelial de
} Agaricus bisporus

\author{
Yazmin C. Díaz-Martínez ${ }^{1}$, Griselda K. Guillén ${ }^{2}$, José E. Sánchez ${ }^{2}$ \\ ${ }^{1}$ Universidad Autónoma de Chiapas, Instituto de Biociencias, Blvd. Príncipe Akishino S/N, Col. Solidaridad 2000, Tapachula \\ Chiapas, Mexico, C.P. 30798. \\ ${ }^{2}$ El Colegio de la Frontera Sur, Carretera Antiguo Aeropuerto km 2.5, Tapachula, Chiapas, Mexico, C.P. 30700.
}

\section{RESUMEN}

Antecedentes: El desarrollo de ciertos microorganismos durante la preparación del sustrato para cultivar Agaricus bisporus es de gran interés por la conversión de material orgánico, y por la excreción de metabolitos con actividades reguladoras de crecimiento que pueden afectar los procesos de desarrollo del hongo. Mejorar la presencia de estos organismos benéficos en el sustrato puede ser una alternativa biotecnológica para optimizar el desarrollo de A. bisporus.

Objetivo. Identificar microorganismos termófilos en un sustrato pasteurizado por autocalentamiento con efecto promotor del crecimiento al usarse para cultivar A. bisporus.

Métodos: Diferentes microorganismos fueron aislados y seleccionados a 45 y $55^{\circ} \mathrm{C}$. Fueron probados en su capacidad para producir sideróforos, consumir 1-octen-3-ol, y solubilizar fosfato, así como en cocultivo con A. bisporus para determinar el efecto de crecimiento en agar papa dextrosa (APD) y en pasto pangola estéril (Digitaria eriantha). Resultados: De 106 microorganismos aislados, 88 \% fueron capaces de crecer en presencia de 1-octen-3-ol, mientras que $1 \%$ tuvo capacidad de producir sideróforos y $55 \%$ tuvo la habilidad para solubilizar fosfatos. Las cepas Bacillus hisashii ECS-B-65, B. licheniformis ECS-B-78, Rhizomucor pusillus ECS-710 y ECS-712, Aspergillus fumigatus ECS-709 y Thermomyces sp. ECS-711 presentaron efecto positivo en el crecimiento de A. bisporus.

Palabras clave: hongos comestibles, cultivo de hongos, hongos portobello, Digitaria eriantha

\section{ABSTRACT}

Background: Certain microorganisms during the preparation of substrate for growing Agaricus bisporus are of great interest for the conversion of organic material and for the excretion of a wide range of metabolites with growth regulation activities that may affect the mycelial growth processes and mushroom yield. Adding beneficial microorganisms in the substrate may be a biotechnological alternative to optimize A. bisporus cultivation.

Objective: Isolate and evaluate thermophilic microorganisms from self-heating pasteurized substrate with growth-promoting effects on A. bisporus cultivation.

Methods: Different microorganisms were isolated and selected at 45 and $55{ }^{\circ} \mathrm{C}$. They were tested for siderophore production, 1-octen-3-ol consumption, and phosphate solubilization in coculture with A. bisporus to determine their growth effects on potato dextrose agar (PDA) and on sterile pangola grass (Digitaria eriantha).

Results: Of the 106 microorganisms isolated, $88 \%$ were able to grow in the presence of 1 -octen-3-ol, while $1 \%$ had the capacity to produce siderophores, and $55 \%$ had the ability to solubilize phosphate. The strains Bacillus hisashii ECS-B-65, B. licheniformis ECS-B-78, Rhizomucor pusillus ECS-710 and ECS-712, Aspergillus fumigatus ECS-709, and Thermomyces sp. ECS-711 were found to have a positive effect on A. bisporus mycelial growth.

Keywords: edible mushrooms, mushroom cultivation, Portobello mushrooms, Digitaria eriantha

\section{ARTICLE HISTORY}

Received 13 August 2019 / Accepted 13 December 2019

Published on line: 31 December 2019
CORRESPONDING AUTHOR

\u José E. Sánchez, esanchez@ecosur.mx

ORCID 0000-0003-0535-4302 


\section{INTRODUCTION}

There is a trend towards diversifying the production of edible mushrooms in the world, although in Europe and in the Americas, the most cultivated fungus by far is currently Agaricus bisporus (J.E. Lange) Imbach. This species of mushroom represents approximately $90 \%$ of the total production of edible mushrooms in most countries (Sánchez et al., 2018).

Agaricus bisporus is commercially cultivated on organic materials such as wheat straw, manure, and corncob, requiring an important treatment including composting and pasteurization to produce a selective substrate that promotes the mycelial growth and fruiting of mushrooms (Song et al., 2014).

The composting process occurs naturally as a consequence of the microbial activity on the wet raw material and is considered essential to develop the final quality of the compost (Souza et al., 2014). Due to the microbial metabolism of sugars, the temperature inside the compost increases, and the mesophilic microbiota is replaced by the thermophilic microbiota. The development of certain species of bacteria and fungi are of great interest not only for the conversion of organic material but also for the excretion of a wide range of metabolites with growth regulation activities (Vijay and Pathak, 2014). These organisms may have metabolic functions such as siderophore production, the ability to solubilize phosphate, hormone production, antibiotic production, nitrogen fixation or the ability to synthesize or degrade metabolites such as 1-octen-3-ol that affect the processes of mushroom development and differentiation. Addition of beneficial organisms in the substrate may be a biotechnological alternative to optimize the development of commercial production of A. bisporus (Sánchez and Royse, 2017). A well-colonized substrate may increase mushroom yield with more fruiting bodies during flushes (Kabel et al., 2017; Aguilar Pontesa et al., 2018). However vigorous mycelial growth is no guarantee of early formation and mushroom production. Often the exact opposite is true depending on the $\mathrm{C} / \mathrm{N}$ ratio and microorganisms on the cover layer and on the cultivation substrate (Ferreira et al., 2009).

The compost in which mushroom is traditionally cultivated has been reported as a suitable habitat for the development of thermophilic fungi, among them Mycothermus thermophilus (Cooney \& R. Emers.) X. Wei
Wang, Houbraken \& D.O. Natvig (synonym of Scytalidium thermophilum), Malbranchea cinnamomea (Lib.) Oorschot \& de Hoog (synonym Malbranchea sulfurea) and Myriococcum thermophilum (Fergus) $\mathrm{Aa}$, which stimulate the mycelial growth and production of $A$. bisporus (Straatsma et al., 1991, 1994; Sánchez, 2007; Sánchez et al., 2008) by reducing the concentration of ammonium, immobilizing nutrients, and producing metabolites that can inhibit competing organisms. After the thermophilic fungi colonize the substrate at 45$50{ }^{\circ} \mathrm{C}$, the substrate is cooled down (Zhang et al., 2019) and thermophiles diminish in activity or die and leave as residues their cell membranes, which are composed of polysaccharides, fatty acids such as linoleic acid and proteins that constitute a rich reserve for $A$. bisporus (Fermor and Wood, 1991).

Alternative methods for substrate preparation without the generation of odor have been studied as an improvement of the traditional method of cultivation with two phases for the white button mushroom (Till, 1962; Sánchez and Royse, 2001; Bechara et al., 2005). Self-heating pasteurization method is an alternative to prepare and pasteurize the substrate in only $45 \mathrm{~h}$ in order to obtain biological efficiency values superior to $100 \%$ on A. bisporus cultivation (Colmenares et al., 2017; Morales and Sánchez, 2017). This is an important advantage because it allows similar mushroom yields with a decrease of the processing time compared to the traditional method that takes between 10 and 21 days (Samp, 2007). Therefore, the objective of this work was to isolate, select and identify thermophilic microorganisms in self-heating pasteurized raw material and determine potential promoting effects of those microorganisms on A. bisporus mycelial growth.

\section{MATERIALS AND METHODS}

\section{Microorganisms}

Commercial spawn of $A$. bisporus var. portobello Heirloom cultivated on millet grain was purchased from Amycel (San Miguel de Allende, Guanajuato, Mexico). The thermophilic microbiota used in this study was isolated directly from batches of pangola grass (Digitaria eriantha Steud) in the pasteurization process and in the mycelial growth of A. bisporus and preserved in the Mycological Collection of El Colegio de la Frontera Sur (Ecosur), Mexico. The acronym ECS used to name all strains stands for Ecosur. 


\section{Self-Heating Pasteurization}

For pasteurizing pangola grass, Avendaño and Sánchez (2013) and Morales and Sánchez (2017) methods were followed. These methods consisted of the use of a $1 \mathrm{~m}^{3}$ wooden box covered with a $2 \mathrm{~cm}$ polyurethane layer and with 50 holes evenly distributed at the bottom of the crate to provide aeration to the raw material. This crate also had a hole in the front in each of three levels of the drawer: $15 \mathrm{~cm}$ from the surface $\left(L_{1}\right)$, to the center $\left(L_{2}\right)$ and $15 \mathrm{~cm}$ above the bottom $\left(L_{3}\right)$, to allow temperature readings with bimetallic thermometers $30 \mathrm{~cm}$ long. Three pasteurization trials were performed using $90 \mathrm{~kg}$ of dry raw material mixed with $2 \%$ calcium hydroxide and humidity adjusted to $65 \%$. It lasted $45 \mathrm{~h}$ with manual turning of the substrate after $30 \mathrm{~h}$ of processing.

\section{Isolation and physiological features}

The isolation of bacteria and fungi was carried out by serial dilutions. Samples of pangola grass were collected from three different points (Levels 1, 2 and 3) of a batch in the process of self-heating pasteurization to ultimately form a composite sample of $10 \mathrm{~g}$. This sample was suspended in $90 \mathrm{~mL}$ of saline solution and stirred for $15 \mathrm{~min}$. Dilutions to $10^{-6}$ were prepared and $100 \mu \mathrm{L}$ of these dilutions were inoculated by cross-streaking on solid nutrient agar (NA), Czapek agar and malt-extract agar (MEA) plates to isolate a wide variety of microorganisms. The plates were incubated at two different temperatures $\left(45\right.$ and $55^{\circ} \mathrm{C}$ ) until the appearance of individual colonies, which were selected according to their colonial morphology and subcultured until the confirmation of the purity of the cultures. Samples were taken at $0 \mathrm{~h}(\mathrm{~B}), 30 \mathrm{~h}(\mathrm{R})$, and $45 \mathrm{~h}$ of the pasteurization process and the last one also corresponds when the substrate was inoculated with $A$. bisporus spawning or 0 day (S), 7 days ( $1 \mathrm{~W})$, and 14 days (2W) of $A$. bisporus mycelial growth after spawning. Samples at $0 \mathrm{~h}$ were also the beginning of pasteurization process, at $30 \mathrm{~h}$ the moment of substrate turning, at $45 \mathrm{~h}$ the end of pasteurization. In addition, direct isolation of fungi was performed from the raw material during the pasteurization process by placing $5 \mathrm{~g}$ of pangola grass on the surface of MEA plates. Subsequently, the plates were incubated for 5 days at 45 or $55^{\circ} \mathrm{C}$ until fungal colonies appeared.

Isolated microorganisms were characterized by Gram stain (bacteria only), micro- and macroscopically, and they were tested for the ability to produce siderophores (Schwyn and Neilands, 1987; Luna et al., 2013), grow on 1-octen 3-ol (Zarenejad et al., 2012) and solubilize phosphate (Sundara and Sincha, 1963).

\section{Extraction of DNA and analysis of ribosomal region sequences} Isolated microorganisms showing positive effect on the mycelial growth of $A$. bisporus were selected for molecular identification. The selected bacterial strains were cultured in liquid nutritive medium and malt extract, and then the DNA was extracted with the AquaPure Genomic DNA Kit (Bio-Rad Cat. No. 732-6340), following the manufacturer's instructions, and $50 \mu \mathrm{L}$ of DNA was obtained.

For the extraction of fungal DNA, the protocol described by Karthikeyan et al. (2010) was adapted. The lysis TES buffer was supplemented with PVP (polyvinylpyrrolidone) at $1 \%$, and digestion with RNase was carried out before precipitation with isopropanol:isoamyl alcohol. Subsequently, the DNA extracted from both bacteria and fungi was visualized by electrophoresis in a $0.8 \%$ agarose gel.

One microliter of different dilutions (1:20 and 1:50) was used to perform the PCR using the ITS4 (5' TCCTCCGCTTATTGATATGC $3^{\prime}$ ) and ITS5 ( $5^{\prime}$ GGAAGTAAAAGT CGTAACAAGG 3') (White et al., 1990) primers for fungi and fD1 (direct) (5' AGAGTTTGATCCTGGCTCAG 3') and rD1 (reverse) (5' AAGGAGGTGATCCAGCC $3^{\prime}$ ) primers for bacteria (Weisburg et al., 1991) in a total reaction volume of $25 \mu \mathrm{L}$ : 1X Buffer for PCR, 0.2 $\mathrm{mM}$ dNTPs, $0.2 \mathrm{pM}$ each primer, $1.5 \mathrm{mM} \mathrm{MgCl}$ and $1 \mathrm{U}$ Taq polymerase. PCR conditions were as follows: an initial denaturation step at $94{ }^{\circ} \mathrm{C}$ for $5 \mathrm{~min}$, followed by 40 cycles of $1 \mathrm{~min}$ at $95^{\circ} \mathrm{C}$, an annealing step for $30 \mathrm{~s}$ at $53{ }^{\circ} \mathrm{C}$ for bacteria or $1 \mathrm{~min}$ at $55^{\circ} \mathrm{C}$ for fungi, followed by an extension step for $1 \mathrm{~min}$ at $72^{\circ} \mathrm{C}$ and a final extension for $5 \mathrm{~min}$ at $72{ }^{\circ} \mathrm{C}$.

PCR products were visualized by electrophoresis in a $1 \%$ agarose gel. Once verified, the PCR products were purified by the Quantum Prep ${ }^{\circledR}$ PCR Kit Kleen Columns (Bio-Rad, Cat. No. 732-6300) and then stored at $-20{ }^{\circ} \mathrm{C}$ until the products were sent to Macrogen Inc. (Seoul, Korea) for sequencing. The sequences were assembled and edited with MEGA7 $®$ software. Subsequently, they were analyzed using the BLAST tools in the GenBank databases (https:// www.ncbi.nlm.nih.gov/) and KEGG (http://www.genome.jp/kegg/). 


\section{Effect of microorganism on Agaricus bisporus mycelial growth}

Of the 106 isolates, 34 microorganisms were selected to evaluate their effect on the growth rate of $A$. bisporus in two ways: 1) according to Rainey (1991), in the center of a Petri dish containing PDA, an A. bisporus disc was inoculated, and after 4 days of incubation at $24{ }^{\circ} \mathrm{C}$, each of the microorganisms evaluated was inoculated in triplicate on the surface of the culture medium at $20 \mathrm{~mm}$ of the edge of $A$. bisporus colony and 2) in glass tubes with substrate (Sánchez and Royse, 2001) (65\% moisture, at $24{ }^{\circ} \mathrm{C}$ ) that was colonized with the microorganism being tested. A control was inoculated with $A$. bisporus only, without any other microorganism (Sánchez and Royse, 2001).

To obtain the bacterial inoculum, each strain was cultured in liquid medium (nutritive medium, Czapek or malt extract) at 45 or $55{ }^{\circ} \mathrm{C}$ for $24 \mathrm{~h}$ with constant agitation at $170 \mathrm{rpm}$. Subsequently, the cultures were centrifuged at 10,000 $\mathrm{G}$ for $15 \mathrm{~min}$; the sediment was suspended in a retentive solution containing in $\mathrm{g} \mathrm{L}^{-1}$ : $0.09 \mathrm{NaCl}, 3.35 \mathrm{Na}_{2} \mathrm{HPO}_{4}$ and $2.1 \mathrm{KH}_{2} \mathrm{PO}_{4}$. For fungal strains, $20 \mathrm{~g}$ pangola grass (65\% humidity) was placed on a plate and sterilized in an autoclave at $121{ }^{\circ} \mathrm{C}$ for $40 \mathrm{~min}$. Then, the fungus being tested was inoculated on the grass and incubated at $45{ }^{\circ} \mathrm{C}$ until complete colonization. This substrate was aseptically introduced into sterile glass tubes containing 5 grains of $A$. bisporus inoculum. The control in this case contained the substrate without fungus and with $A$. bisporus spawn. Moisture was adjusted with the retentive solution (Sánchez and Royse, 2001).

In both cases, (plates or tubes), measurements of the mycelial growth of $A$. bisporus were made every 5 days. In Petri dishes, these measurements were made at the bottom of the plate considering the radial growth. For the tubes, the measurements were made at three equidistant points around the circumference of the tube. The linear extension rate of the mycelial growth of A. bisporus ( $\mathrm{kr}$ ) was calculated by adjusting the linear growth function $\mathrm{y}=\mathrm{kr} \mathrm{x}+\mathrm{c}$ (where $\mathrm{y}$ is the distance, and $x$ is the time), which was expressed in $\mathrm{mm} /$ day.

\section{Design of treatments and statistical analysis}

A completely randomized unifactorial design with three repetitions was used. The data obtained were subjected to an analysis of variance (ANOVA) and a comparison test of means (Tukey's test, $P \leq 0.05$ ) using the statistical package $\mathrm{R}$.

\section{RESULTS}

\section{Evaluation of physicochemical parameters of the substrate} during pasteurization

Figure 1 shows the evolution of the temperature and $\mathrm{pH}$ of the substrate during the $45 \mathrm{~h}$ of the self-heating pasteurization process. The temperature in the box with $90 \mathrm{~kg}$ (dry basis) of substrate reached values of 60 ${ }^{\circ} \mathrm{C}$ and higher after $20 \mathrm{~h}$ of processing in levels 1 and 2 , and at the time of turning ( $30 \mathrm{~h}$ of processing), the substrate in these two levels had been maintained at this temperature for more than $9 \mathrm{~h}$. At the time of turning, the batch of substrate located in level 3 (bottom) was placed in level 1 (upper part), with which it had a notable increase in temperature that led to a treatment of at least $6 \mathrm{~h}$ at $60^{\circ} \mathrm{C}$ in the whole batch. With these results, it was considered that all of the material was pasteurized at the end of the process ( $45 \mathrm{~h}$ ). In parallel, the $\mathrm{pH}$ value decreased from 9.1 to 6.8 during this time.
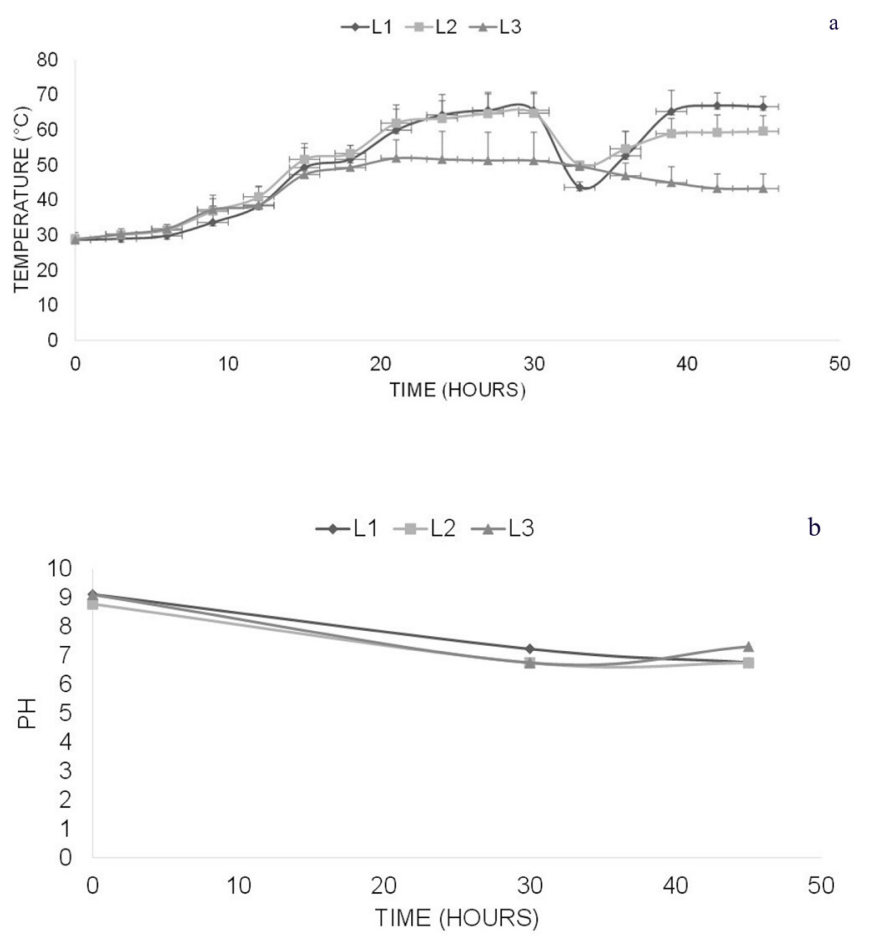

Figure 1. Change in a) substrate temperature and b) substrate $\mathrm{pH}$ (pangola grass $+2 \%$ lime) during the self-heating pasteurization process, in three levels of the substrate: at $15 \mathrm{~cm}$ below the surface (L1), at the center (L2) and $15 \mathrm{~cm}$ above the bottom (L3). 


\section{Isolation of microorganisms}

The population of total cultivable microorganisms in the substrate ranged between $2.6 \times 10^{4}$ to $4.6 \times 10^{8}$ CFU $\mathrm{g}^{-1}$ at $45{ }^{\circ} \mathrm{C}$ (Figure 2) and $2.3 \times 10^{5}$ to $6.5 \times 10^{8}$ $\mathrm{CFU} \mathrm{g}^{-1}$ at $55^{\circ} \mathrm{C}$ (Figure 3), as determined from five measurements during the entire process (starting from the beginning of pasteurization until two weeks after substrate spawning).

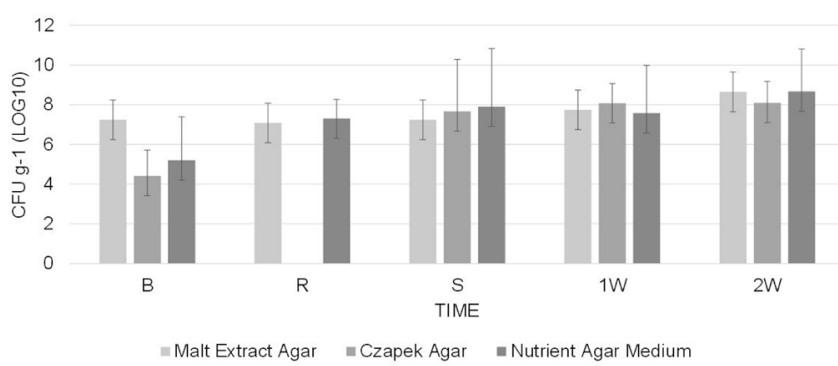

FIGURE 2. Population of total microorganisms associated with the culture of $A$. bisporus on pangola grass isolated at $45^{\circ} \mathrm{C}$ at different times of the pasteurization process and culture. B: beginning of pasteurization, R: turning of substrate, $\mathrm{S}$ : end of pasteurization (time of spawning A. bisporus), 1W: at 7 days of mycelial growth and $2 \mathrm{~W}$ : at 14 days of mycelial growth. The vertical bars indicate the standard deviation of the means of three repetitions.

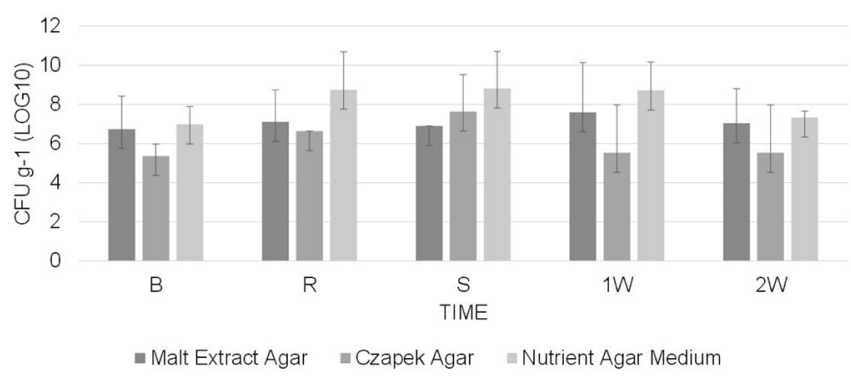

FIGURE 3. Population of total microorganisms associated with the culture of Agaricus bisporus on pangola grass isolated at $55^{\circ} \mathrm{C}$ at different times of the pasteurization process and culture. B: beginning of pasteurization, R: turning of substrate, $\mathrm{S}$ : end of pasteurization (time of spawning $A$. bisporus), $1 \mathrm{~W}$ : at 7 days of mycelial growth and 2W: at 14 days of mycelial growth. The vertical bars indicate the standard deviation of the means of three repetitions.
Based on their morphology and abundance, 57 and 49 microbial isolates were obtained at 45 and $55{ }^{\circ} \mathrm{C}$ respectively (Tables 1 and 2). Of these, 47 and 49 corresponded to bacteria at 45 and $55^{\circ} \mathrm{C}$ respectively and 9 corresponded to fungi at $45^{\circ} \mathrm{C}$. No fungi were isolated at $55{ }^{\circ} \mathrm{C}$. The 96 isolated bacteria were Gram positive. Regarding the shape of the bacterium colonies, punctate, granular, irregular and circular colonies were found, and circular shapes (70\% and $69 \%$ ) full edges (61\% and $55 \%$ ), creamy consistencies (58\% and 86 $\%$ ) and convex colonies (60\% and $39 \%$ ) were the predominant morphologies at 45 and $55^{\circ} \mathrm{C}$, respectively.

\section{Physiological features}

All isolated microorganisms were evaluated for siderophore production, growth capacity in the presence of 1-octen-3-ol, and phosphate solubilization (Tables 3 and 4). Of the 106 isolates, only strain ECS-709 had the ability to produce siderophores, while $91 \%$ were able to grow in the presence of 1-octen-3-ol, and $57 \%$ had the ability to solubilize phosphate. From these results, 34 strains showing siderophore production, growth in 1-octen-3-ol or phosphate solubilization (19 and 15 microorganisms at 45 and $55^{\circ} \mathrm{C}$, respectively) were selected to evaluate the effect on the growth of $A$. bisporus. Regarding the effect of the selected microorganisms on the radial growth of $A$. bisporus on PDA plates, it was found that the fungal strains ECS-711 and ECS712 presented a positive effect $(\alpha=0.05)$, increasing the radial extension rate of $A$. bisporus by 106 and $208.8 \%$, while the rest of the fungi showed no effect. In contrast, $64 \%$ of the bacteria showed an inhibitory effect, and $36 \%$ of them showed no effect with respect to the control (Tables 3 and 4). In the growth tests with substrate in tubes, fungal strains ECS-709, ECS-710 and ECS-712 showed highly significant growth-promoting effects on $A$. bisporus $(\alpha=0.05)$ with respect to the

TABLE 1. Culture characteristics of microorganisms isolated at $45^{\circ} \mathrm{C}$ associated with different stages of cultivation of Agaricus bisporus on self-heating pasteurized substrate made on pangola grass

\begin{tabular}{|c|c|c|c|c|c|c|c|c|c|}
\hline \multirow{2}{*}{$\begin{array}{l}\text { TIME OF } \\
\text { ISOLATION }\end{array}$} & \multicolumn{2}{|c|}{ MICROORGANISMES } & \multirow[t]{2}{*}{ Gram } & \multicolumn{5}{|c|}{ CHARACTERISTICS OF THE COLONY } & \\
\hline & BACTERIA & FUNGI & & Colour & FORM & EDGE & CONSISTENCE & ELEVATION & \\
\hline & & ECS-709 & & White & Circular & Entire & & Convex & $\begin{array}{l}\text { Green } \\
\text { spores }\end{array}$ \\
\hline & & ECS-710 & & Beige & Circular & Entire & & Convex & \\
\hline & ECS-B-54 & & + & White & Circular & Entire & Creamy & Convex & \\
\hline
\end{tabular}


concluye Tabla 1.

\begin{tabular}{|c|c|c|c|c|c|c|c|c|c|}
\hline \multirow{2}{*}{$\begin{array}{l}\text { TIME OF } \\
\text { ISOLATION }\end{array}$} & \multicolumn{2}{|c|}{ MICROORGANISMES } & \multirow[t]{2}{*}{ Gram } & \multicolumn{5}{|c|}{ CHARACTERISTICS OF THE COLONY } & \\
\hline & BACTERIA & FUNGI & & COLOUR & FORM & EDGE & CONSISTENCE & Elevation & \\
\hline \multirow{4}{*}{$\begin{array}{l}\text { Removal of the } \\
\text { substrate (R) }\end{array}$} & & ECS-711 & & White & Circular & Entire & & Convex & $\begin{array}{l}\text { Black } \\
\text { spores }\end{array}$ \\
\hline & & ECS-712 & & $\begin{array}{c}\text { Beige } \\
\text { grayish }\end{array}$ & Circular & Entire & & Convex & \\
\hline & ECS-B-55 & & + & Hyaline & Irregular & Undulated & Gelatinous & Pulvinate & \\
\hline & ECS-B-56 & & + & Hyaline & Circular & Undulated & Gelatinous & Pulvinate & \\
\hline \multirow{3}{*}{$\begin{array}{l}\text { Spawning of } \\
\text { Agaricus bispo- } \\
\text { rus (S) }\end{array}$} & ECS-B-57 & & + & Yellow & Circular & Entire & Creamy & Convex & \\
\hline & ECS-B-58 & & + & Yellow & Irregular & Undulated & Creamy & Pulvinate & \\
\hline & ECS-B-59 & & + & Red & Circular & Undulated & Creamy & Pulvinate & \\
\hline \multirow{5}{*}{$\begin{array}{l}7 \text { days after } \\
\text { spawning Aga- } \\
\text { ricus bisporus } \\
\text { (1W) }\end{array}$} & & ECS-713 & & White & Circular & Entire & & Convex & \\
\hline & & ECS-714 & & Green & Circular & Entire & & Convex & $\begin{array}{l}\text { Green } \\
\text { spores }\end{array}$ \\
\hline & & ECS-715 & & Green & Granulated & Entire & & Convex & $\begin{array}{c}\text { Whitespace } \\
\text { periphery }\end{array}$ \\
\hline & ECS-B-60 & & + & Yellow & Irregular & Undulated & Creamy & Pulvinate & \\
\hline & ECS-B-61 & & + & Yellow & Irregular & Undulated & Gelatinous & Pulvinate & \\
\hline \multirow{4}{*}{$\begin{array}{l}14 \text { days after } \\
\text { spawning Aga- } \\
\text { ricus bisporus } \\
\text { (2W) }\end{array}$} & & ECS-716 & & White & Circular & Entire & & Convex & $\begin{array}{l}\text { Gray } \\
\text { spores }\end{array}$ \\
\hline & & ECS-717 & & White & Circular & Entire & & Convex & $\begin{array}{l}\text { Brown } \\
\text { spores }\end{array}$ \\
\hline & ECS-B-62 & & + & Hyaline & Circular & Entire & Gelatinous & Convex & \\
\hline & ECS-B-63 & & + & Hyaline & Irregular & Undulated & Gelatinous & Pulvinate & \\
\hline
\end{tabular}

TABLE 2. Culture characteristics of microorganisms isolated at $45{ }^{\circ} \mathrm{C}$ associated with different stages of cultivation of Agaricus bisporus on self-heating pasteurized substrate made on pangola grass

\begin{tabular}{|c|c|c|c|c|c|c|c|}
\hline \multirow[t]{2}{*}{ TIME OF ISOLATION } & \multirow{2}{*}{$\begin{array}{l}\text { STRAINS OF } \\
\text { BACTERIAS }\end{array}$} & \multirow[t]{2}{*}{ Gram } & \multicolumn{5}{|c|}{ CHARACTERISTICS OF THE COLONY } \\
\hline & & & Colour & Form & EDGE & Consistence & Elevation \\
\hline \multirow{3}{*}{$\begin{array}{c}\text { Removal of the sub- } \\
\text { strate (R) }\end{array}$} & ECS-B-64 & + & Yellow & Circular & Entire & Creamy & Convex \\
\hline & ECS-B-65 & + & White & Irregular & Undulated & Creamy & Pulvinate \\
\hline & ECS-B-66 & + & Hyaline & Circular & Undulated & Gelatinous & Pulvinate \\
\hline \multirow{4}{*}{$\begin{array}{c}\text { Spawning of Agaricus } \\
\text { bisporus (S) }\end{array}$} & ECS-B-67 & + & Yellow & Circular & Undulated & Creamy & Pulvinate \\
\hline & ECS-B-68 & + & Hyaline & Circular & Entire & Creamy & Pulvinate \\
\hline & ECS-B-69 & + & Yellow & Circular & Entire & Creamy & Pulvinate \\
\hline & ECS-B-70 & + & Yellow & Circular & Entire & Creamy & Pulvinate \\
\hline \multirow{6}{*}{$\begin{array}{c}7 \text { days after spawning } \\
\text { Agaricus bisporus } \\
(1 \mathrm{~W})\end{array}$} & ECS-B-71 & + & Yellow & Circular & Entire & Creamy & Convex \\
\hline & ECS-B-72 & + & Yellow & Irregular & Undulated & Creamy & Pulvinate \\
\hline & ECS-B-73 & + & White & Irregular & Undulated & Creamy & Pulvinate \\
\hline & ECS-B-74 & + & White & Irregular & Undulated & Creamy & Pulvinate \\
\hline & ECS-B-75 & + & Yellow & Circular & Entire & Creamy & Convex \\
\hline & ECS-B-76 & + & White & Circular & Entire & Creamy & Convex \\
\hline \multirow{2}{*}{$\begin{array}{c}14 \text { days after spawn- } \\
\text { ing Agaricus bisporus } \\
(2 \mathrm{~W})\end{array}$} & ECS-B-77 & + & White & Irregular & Entire & Creamy & Pulvinate \\
\hline & ECS-B-78 & + & Yellow & Irregular & Undulated & Creamy & Pulvinate \\
\hline
\end{tabular}




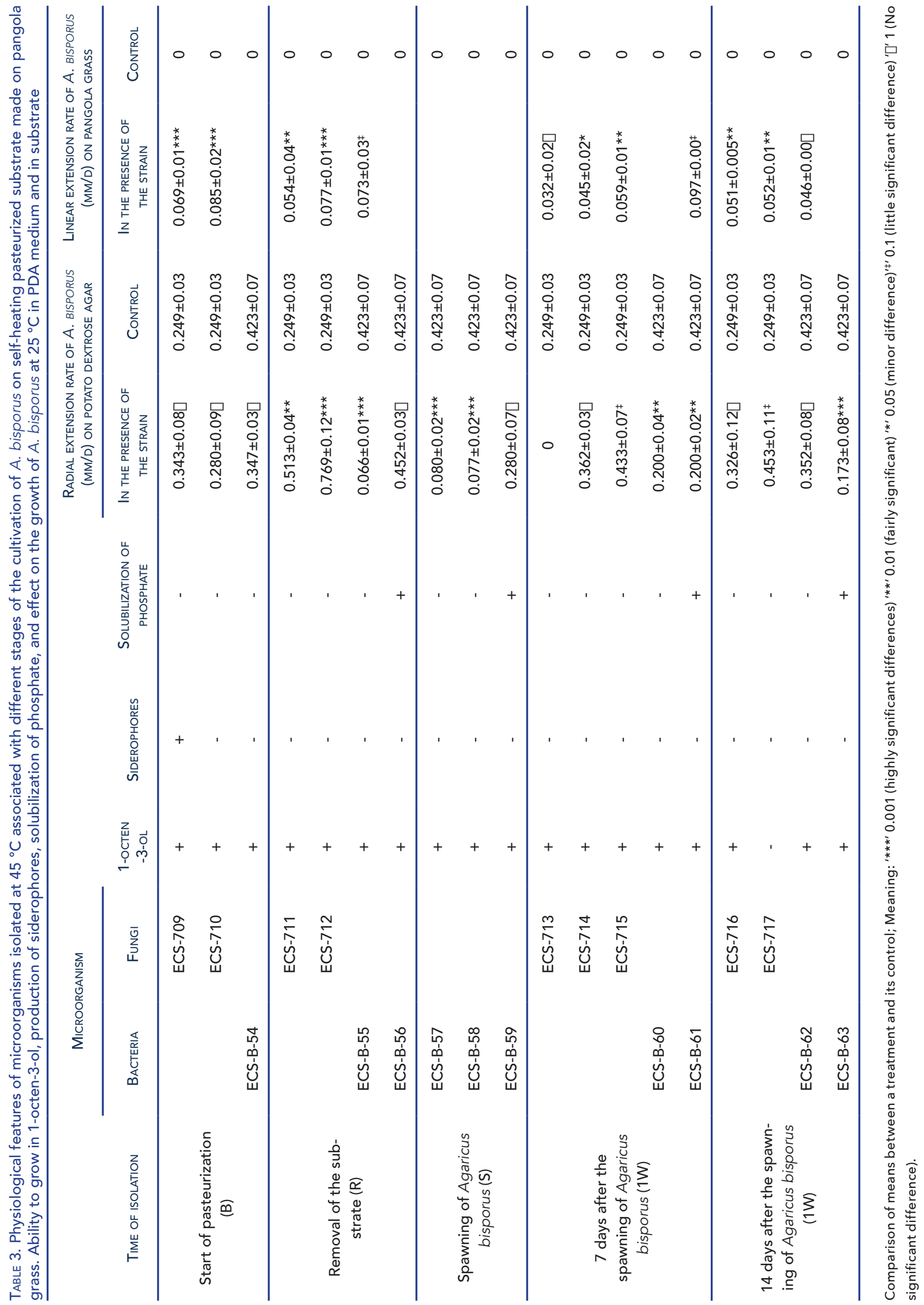




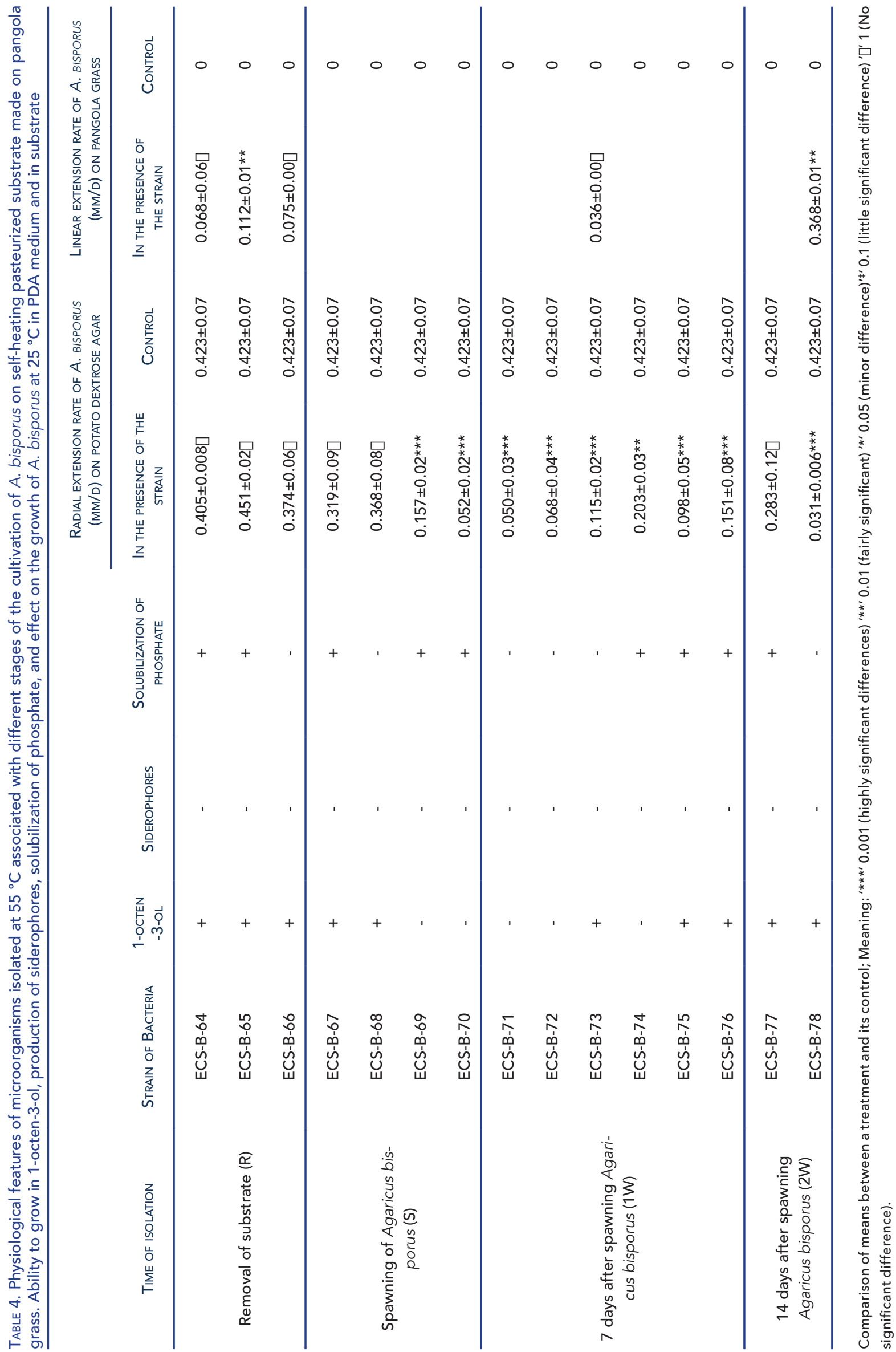


control that presented no growth. Most bacteria also presented a negative or no effect on the growth of $A$. bisporus on pangola grass, except for strains ECS-B-65 and ECS-B-78, which presented a fairly significant ( $\alpha=0.01)$ promoting effect.

\section{Molecular identification of the isolates}

The strains that showed a positive effect on the growth promotion of $A$. bisporus were analyzed phylogenetically by means of 165 (ECS-B-65 and ECS-B-78) and ITS (ECS-709, ECS-710, ECS-711 and ECS- 712) molecular markers. The comparison of sequences obtained from the 16S rRNA gene of the two strains isolated against the $\mathrm{NCBI}$ database indicated that they belonged to the genus Bacillus. Strain ECS-B-65 presented a high percentage of similarity (99\%) with $B$. hisashii and B. thermoamylovorans, while ECS-B-78 presented a high percentage of similarity with $B$. licheniformis (100 \%). Regarding the fungal strains ECS-709, ECS-710, ECS-711 and ECS-712, the sequence of the ITS region indicated that the four isolates belonged to different genera: ECS-709 was similar to Aspergillus fumigatus, ECS-710 and ECS-712 to Rhizomucor pusillus, and ECS-711 was located molecularly as a member of the subdivision Pezizomycotina. Further studies carried out by traditional microscopy and according to its morphological features supported that this strain belonged to the genus Thermomyces according to the description by Ellis (1971). All analyzed sequences showed a similarity between $99 \%$ and $100 \%$ with the GenBank matched sequences (Table 5).

\section{DISCUSSION}

\section{Overview of microorganisms}

In this work, the isolation and identification of thermophilic microorganisms (at 45 and $55{ }^{\circ} \mathrm{C}$ ) during the substrate preparation by self-heating and growth during the cultivation of $A$. bisporus was performed. The development of the temperature during the pasteurization process allowed a thermal treatment of the whole substrate of at least $60^{\circ} \mathrm{C}$ for six hours, which is considered to be enough to achieve pasteurization. It agrees with previous criteria and experiences that used pasteurized substrates by self-heating for the cultivation of Pleurotus spp., A. bisporus and other edible mushrooms (Morales and Sánchez, 2017; Colmenares et al., 2017).

The data regarding the population dynamics of thermophilic microorganisms in pangola grass pasteurized by self-heating varied between $2.6 \times 10^{4}-4.6 \times 10^{8}$ $\mathrm{CFU} \mathrm{g}{ }^{-1}$ at $45^{\circ} \mathrm{C}$ and $2.3 \times 10^{5}-6.5 \times 10^{8} \mathrm{CFU} \mathrm{g}^{-1}$ at $55^{\circ} \mathrm{C}$, similar to what was reported by Souza et al. (2014), who in a study of thermophilic population diversity during phase II of composting for the cultivation of $A$. subrufescens found densities of $2.55 \times 10^{5}-6 \times 10^{5} \mathrm{CFU}$ $\mathrm{g}^{-1}$. These quantities are related to temperature profile, nutrient availability, oxygen concentration, moisture content and pH (Camacho et al., 2014), in addition to the availability of carbon produced by the degradation of lignin associated with the cellulose and hemicellulose of the substrates used (Wood, 1984). It has been reported for the genera Pleurotus and Agaricus in this

TABLE 5. Genetic affiliation of the study strains according to the comparative analysis based on the sequences of the $16 \mathrm{~S}$ and ITS rDNA regions

\begin{tabular}{|c|c|c|c|c|c|}
\hline StRAIN & Data Base & Coverage $(\%)$ & IDENTITY (\%) & Closest relative & $\mathrm{N}^{\circ}$ OF ACCESS OF THE CLOSEST RELATIVE \\
\hline & & 100 & 99 & Bacillus hisashii & AB909962.1 \\
\hline \multirow[t]{2}{*}{ ECS-B-65 } & NCBI Blast & & & & \\
\hline & & 100 & 99 & Bacillus thermoamylovorans & FN397520.1 \\
\hline ECS-B-78 & NCBI Blast & 100 & 100 & Bacillus licheniformis & СР027789.1 \\
\hline ECS-709 & NCBI Blast & 100 & 100 & Aspergillus fumigatus & MH591451.1 \\
\hline ECS-710 & NCBI Blast & 99 & 99 & Rhizomucor pusillus & KJ527032.1 \\
\hline ECS-711 & NCBI Blast & 96 & 100 & Pezizomycotina & KC237297.1 \\
\hline ECS-712 & NCBI Blast & 99 & 99 & Rhizomucor pusillus & KJ527032.1 \\
\hline
\end{tabular}


sense, that the growth and production of the fruiting body depends not only on the fungus itself but also on the bacteria and other fungi on the substrate (Kertesz and Thai, 2018).

During pasteurization, bacteria were the predominant and abundant group of microorganisms, followed by filamentous fungi. Similar values were previously reported in wheat and rice straw compost, in which the prokaryotes along with a few fungi predominated during the first days of composting, while the actinomycetes prevailed during the final period of composting (Atkey and Wood, 1983; Cahyani et al., 2004). It has been described that some species of Bacillus, Pseudomonas and actinomycetes play an important role in the assimilation and transformation of ammonia, which is highly toxic to the mycelial growth of Agaricus species (Ryckeboer et al., 2003, Colauto et al., 2016). The presence of bacilli in the substrate for edible fungi after pasteurization is explained because they are fast growing and able to survive at temperatures greater than $55{ }^{\circ} \mathrm{C}$ through thermoresistance mechanisms (Torres et al., 2016).

Among the most abundant bacterial taxa in pasteurized substrates for the cultivation of species of Agaricus and Pleurotus are Pseudoxanthomonas taiwanensis, Thermus and bacilli (Bacillus, Geobacillus, and Ureibacillus) (Kertesz et al., 2016; Vajna et al., 2012), which produce $\alpha$-amylases that degrade starch, as does Aspergillus spp., which also produce proteases, glucoamylases and pectinases. Bacillus produces extracellular enzymes that breakdown polysaccharides, nucleic acids and lipids, allowing the mushroom to use these products as carbon sources and electron donors (Cariello et al., 2007). Some species of Bacillus and Pseudomonas have the enzymatic capacity to degrade various cell wall components of certain fungi (Vargas et al., 2007).

The main role of the thermoresistant filamentous fungi that colonize the substrate during composting is to degrade lignocellulose, decreasing the amount of fiber and increasing the availability of the substrate for A. bisporus. These filamentous fungi are essential for the transformation of the substrate; in this study, they were represented by the strains $A$. fumigatus ECS-709, Thermomyces sp. ECS-711 and Rhizomucor pusillus ECS-710 and ECS-712, which were isolated during the manual turning of the substrate (R). Zhang et al. (2014) identified both Aspergillus spp. and Myceliophthora spp., as very abundant members of the compost stages of edible mushrooms. Moreover, the genus Rhizomucor has been isolated from decomposing soil, fruits or vegetables, fermentation and compost of organic matter. Rhizomucor spp., $R$. variabilis, are thermophilic in nature and can grow at $54{ }^{\circ} \mathrm{C}$ (Salar and Aneja, 2007).

\section{Isolation and physiological features}

In this work, only the strain ECS-709 of Aspergillus fumigatus presented the capacity to produce siderophores. Other studies (Singh et al., 2012; Zarenejad et al., 2012) have reported a higher proportion of siderophore-producing bacteria that are indirectly involved in the increase in mushroom production. However, Torres et al. (2016), when studying the mycosphere in a substrate for the culture of $P$. ostreatus, determined that $46 \%$ of the isolates were able to produce siderophores. It is appropriate to observe that, in those works, mesophilic microorganisms were isolated and cultured at room temperature, while in the present work, emphasis was placed on the search for thermophilic microorganisms, which could contribute to explaining the difference in the characteristics of the isolated microbiota.

Of the 34 strains selected to evaluate the effect on mycelial growth of $A$. bisporus, $91 \%$ were able to grow in the presence of 1-octen-3-ol. It has been found that in cultures in vitro, the compound 1-octen-3-ol inhibits the formation of primordia but does not inhibit the mycelial growth of fungi. In the culture of $A$. bisporus, the crop yield is related to the consumption of 1-octen3-ol by Pseudomonas putida (Zarenejad et al., 2012). It has been shown that 1-octen-3-ol inhibits spore germination of Penicillium paneum (Chitarra et al., 2004) and Aspergillus nidulans (Herrero et al., 2011) and has been found to suppress the change in the reproductive phase in A. bisporus (Noble et al., 2009). The ability to consume 1-octen-3-ol could increase the yield of A. bisporus cultivation because it is directly related to the growth and development of the fungus (Eastwood et al., 2013) and the initiation of basidiocarps, and 1-octen-3-ol could also be used as an energy source for the beneficial microorganisms present in the crop (Noble et al., 2009).

In the phosphate solubilization test, $57 \%$ of the microorganisms showed this capacity, and among them was the strain ECS-B-65 belonging to the genus Bacillus. Phosphorus is an essential macronutrient for the 
growth and development of plants and is involved in important metabolic pathways, such as photosynthesis, biological oxidation, nutrient uptake and cell division (Gupta et al., 2012). Filamentous fungi, such as those from the genera Aspergillus and Penicillium, have been recognized for their ability to solubilize insoluble phosphates by the release of organic acids such as citric, oxalic, malic and gluconic acids (Singh and Reddy, 2011).

\section{Effect on the growth of Agaricus bisporus}

In this study, strains belonging to the genera Bacillus (ECS-B-65 and ECS-B-78), Rhizomucor (ECS-710 and ECS-712), Aspergillus (ECS-709) and Thermomyces sp. (ECS-711) were found to have a positive effect on the growth of $A$. bisporus. It has been reported that Bacillus promotes the growth of $P$. ostreatus by secreting laccases and inhibiting the growth of Trichoderma harzianum (Velázquez-Cedeño et al., 2008). In the case of $B$. licheniformis, it synthesizes and excretes toxic peptides and bacteriocides that are capable of inhibiting the growth of yeasts, as well as gram-positive and gram-negative bacteria (Watabe et al., 2003). Thermomyces sp. ECS-711 and R. miehei ECS-712 promoted values of 0.51 and $0.76 \mathrm{~mm} /$ day of the radial extension rate (RER) of $A$. bisporus on PDA (Table 3). These results are lower than those reported by Coello et al. (2009), (between 1.4-0.9 mm/day on the substrate without previous colonization of Mycothermus thermophilus), and even lower than the $7 \mathrm{~mm} /$ day reported by Straatsma et al. (1994) when indicating that $M$. thermophilus is positively correlated with the production of mushrooms and strongly stimulates the mycelial growth of $A$. bisporus.

Op den Camp et al. (1990) indicated that the presence of $M$. thermophilus is important for the colonization of the substrate by $A$. bisporus. However, during this study, it was not possible to isolate this micromycete or other thermophilic fungi reported with similar characteristics that stimulate the growth of $A$. bisporus at the levels previously reported (Straatsma et al., 1991; Sánchez et al., 2008). All of the above findings indicate that the dynamics of microbial growth during pasteurization by self-heating allow the incipient presence of thermophilic microorganisms that promote the growth of $A$. bisporus as a consortium, with characteristics such as the consumption of 1-octen-3-ol, solubilization of phosphates, or siderophore production, in such a way that a faster growth of $A$. bisporus is observed with respect to the control grown on sterile substrate but still slow when compared with other more efficient substrates that have previously been reported (compost phase II, substrate colonized with $M$. thermophilus) (Ferreira et al., 2009).

The biological characteristics achieved at the end of $45 \mathrm{~h}$ of pasteurization by self-heating already allow the colonization of the substrate by $A$. bisporus but are insufficient for the colonization of outstanding beneficial microorganisms (such as Mycothermus thermophilus, Myriococcum thermophilum, and actinomycetes), with additional characteristics that promote the fast and competitive growth of $A$. bisporus and thus achieve a truly selective substrate. From this point of view, it is important to highlight that $A$. bisporus grew well though slowly on the self-heating pasteurized substrate, and thus, colonization of this noncomposted substrate may be improved. Therefore, it is interesting for future research to determine if it is worth trying to inoculate the substrate with other beneficial microorganisms at the beginning of the pasteurization by self-heating.

\section{CONCLUSIONS}

Microbial growth during self-heating pasteurization allows to evaluate the incipient presence of thermophilic microorganisms with characteristics such as 1-octen-3ol consumption, phosphate solubilization and siderophores production. 106 thermophilic microorganisms present in the pasteurized Agaricus bisporus culture substrate were isolated.

The microorganisms Bacillus hisashii, B. thermoamylovorans, B. licheniformis, Aspergillus fumigatus, Rhizomucor pusillus (ECS-710 and ECS-712) and Thermomyces sp. that promote the growth of Agaricus bisporus were identified. The effect of mycelial growth was 0.51 and $0.76 \mathrm{~mm} /$ day.

\section{ACKNOWLEDGMENTS}

Authors would like to thank Lilia Moreno Ruiz and Veronica García for their technical support, René H. Andrade Gallegos for identifying Thermomyces sp. and Javier Valle for his help in the statistical analysis of the data. This study was financed with fiscal resources from El Colegio de la Frontera Sur (Ecosur) of Mexico. 


\section{REFERENCES}

Aguilar Pontesa, M.V., A. Patyshakuliyeva, H. Postb, E. Jurakd, K. Hildéne, M. Altelaarb, A. Heckb, M.A. Kabeld, R.P. de Vriesa, M.R. Mäkelä, 2018. The physiology of Agaricus bisporus in semi-commercial compost cultivation appears to be highly conserved among unrelated isolates. Fungal Genetics and Biology 112: 12-20.

Atkey, P.T., D.A. Wood, 1983. An electron microscope study of wheat straw composted as a substrate for the cultivation of the edible mushroom (Agaricus bisporus). Journal of Applied Microbiology 55: 293-304.

Avendaño, R.J., J.E. Sánchez, 2013. Self-pasteurised substrate for growing oyster mushrooms (Pleurotus spp.). African Journal of Microbiology Research 7(3): 220-226.

Bechara, M., P. Heinemann, P. Walker, C.P. Romaine, 2005. Cultivation of Agaricus bisporus on a mixture of cereal grain spawn and delayed-release nutrient supplement. Mushroom News 53 (8): 6-10.

Cahyani, V.R., K. Matsuya, S. Asakawa, M. Kimura, 2004. Succession and phylogenetic profile of eukaryotic communities in the composting process of rice straw estimated by PCR-DGGE analysis. Biology and Fertility of Soils 40(5): 334-344.

Camacho, A.D., L. Martínez, H. Ramírez, R. Valenzuela, M. Valdés, 2014. Potencial de algunos microorganismos en el compostaje de residuos sólidos. Terra Latinoamericana 32: 291-300.

Cariello, M.E., L. Castañeda, I. Riobo, 2007. Inoculante de microorganismos endógenos para acelerar el proceso compostaje de residuos sólidos urbanos. Revista de la Ciencia del Suelo y Nutrición Vegetal 7(3): 26-35.

Chitarra, G.S., T. Abee, F.M. Rombouts, M.A. Posthumus, J. Dijksterhuis, 2004. Germination of Penicillium paneum conidia is regulated by 1-octen-3-ol, a volatile self-inhibitor. Applied and Environmental Microbiology 70: 2823-2829.

Coello, M.M., J.E. Sánchez, D.J. Royse, 2009. Production of Agaricus bisporus on substrates pre-colonized by Scytalidium thermophilum and supplemented at casing with protein-rich supplements. Bioresource Technology 100: 4488-4492.

Colauto, N.B., T.R. Fermor, A.F. Eira, G.A. Linde, 2016. Pseudomonas putida stimulates primordia on Agaricus bitorquis. Current Microbiology 72: 482-488.

Colmenares, S., J.E. Sánchez, J. Valle, 2017. Agaricus bisporus production on substrates pasteurized by self-heating. AMB Express 7(1): 135.

Eastwood, D.C., B. Herman, R. Noble, A. Dobrovin, S. Sreenivasaprasad, S. Kerry, K.S. Burton, 2013. Environmental regulation of reproductive phase change in Agaricus bisporus by 1-octen-3-ol, temperature and $\mathrm{CO}_{2}$. Fungal Genetics and Biology 55: 54-66.

Ellis, M.B., 1971. Dematiaceous hyphomycetes. X. Mycological Papers 125: 1-30.

Fermor, T.R., D.A. Wood, 1991. Mushroom compost microbial biomass: a review. Science and Cultivation of Edible Fungi 13: 191200.

Ferreira, S.C., A.R. Santos, C. Braga, R. Silva, D.E. Souza, S.R. Freitas, 2009. Microbial diversity in a bagasse-based compost prepared for the production of Agaricus brasiliensis. Brazilian Journal of Microbiology 40: 590-600.
Gupta, M., S. Kiran, A. Gulati, B. Singh, R. Tewari, 2012. Isolation and identification of phosphate solubilizing bacteria able to enhance the growth and aloin-A biosynthesis of Aloe barbadensis Miller. Microbiology Research 167: 358-363.

Herrero, E., A. Garzia, S. Cordobés, E.A. Espeso, U. Ugalde, 2011. 8-Carbon oxylipins inhibit germination and growth and stimulate aerial conidiation in Aspergillus nidulans. Fungal Biology 115(45): 393-400.

Kabel, M.A., E. Jurak, M.R. Mäkelä, R.P. de Vries, 2017. Occurrence and function of enzymes for lignocellulose degradation in commercial Agaricus bisporus cultivation. Applied Microbiology and Biotechnology 101: 4363-4369.

Karthikeyan, V., S. Patharajan, P. Palani, D. Spadaro, 2010. Modified simple protocol for efficient fungal DNA extraction highly. Global Journal of Molecular Sciences 5: 37-42.

Kertesz, M., K. Safianowicz, T. Bell, 2016. New insights in to the microbial communities and biological activities that define mushroom compost. Science and Cultivation of Edible Fungi 19: 161 165.

Kertesz, M., M. Thai, 2018. Compost bacteria and fungi that influence growth and development of Agaricus bisporus and other commercial mushrooms. Applied Microbiology and Biotechnology 102: 1639-1650.

Luna, L., R.A. Martínez, M. Hernández, S.M. Arvizu, J.R. Pacheco, 2013. Caracterización de rizobacterias aisladas de tomate y su efecto en el crecimiento de tomate y pimiento. Revista Fitotecnia Mexicana 36: 63-69.

Morales, D.V., J.E. Sánchez, 2017. Self heating pasteurization of substrates for culinary-medicinal mushrooms cultivation in Mexico. International Journal of Medicinal Mushrooms 19: 477-484.

Noble, R., P.A. Dobrovin, P.J. Hobbs, J. Pederby, A. Rodger, 2009. Volatile C8 compounds and pseudomonads influence primordium formation of Agaricus bisporus. Mycologia 101(5): 583-591.

Op den Camp, H., C.K. Stumin, G. Straatsma, P.J. Derikx, L.J. Van Griensven, 1990. Hyphal and micelial interaction between Agaricus bisporus and Scytalidium thermophilum on agar media. Microbial Ecology 19: 303-309.

Rainey, P.B., 1991. Effect of Pseudomonas putida on hyphal growth of Agaricus bisporus. Mycological Research 95: 699-704.

Ryckeboer, J., J. Mergaert, K. Vaes, S. Klammer, D. De Clercq, J. Coosemans, J. Swings, 2003. A survey of bacteria and fungi occurring during composting and self-heating processes. Annals of Microbiology 53: 349-410.

Salar, R.K., K.R. Aneja, 2007. Thermophilic fungi: taxonomy and biogeography. Journal of Agricultural Technology 3: 77-107.

Samp, R., 2007. Desarrollo de sistemas de procesamiento de composta para el champiñón Agaricus bisporus. In: Sánchez J.E., D.J. Royse, H. Leal Lara (eds.), Cultivo, mercadotecnia e inocuidad alimenticia de Agaricus bisporus. El Colegio de la Frontera Sur, Tapachula. Pp. 49-56.

Sánchez, J.E., 2007. Uso de hongos termófilos para la preparación de sustratos. In: Sánchez J.E., D.J. Royse, H. Leal Lara (eds.), Cultivo, mercadotecnia e inocuidad alimenticia de Agaricus bisporus. El Colegio de la Frontera Sur, Tapachula. Pp. 65-74. 
Sánchez, J.E., L. Mejía, D.J. Royse, 2008. Pangola grass colonized with Scytalidium thermophilum for production of Agaricus bisporus. Bioresource Technology 99: 655-662.

Sánchez, J.E., D.J. Royse, 2001. Adapting substrate formulas used for shiitake for production of brown Agaricus bisporus. Bioresource Technology 77: 65-69.

Sánchez, J.E., D.J. Royse, 2017. La biología, el cultivo, y las propiedades nutricionales y medicinales de las setas, Pleurotus spp. El Colegio de la Frontera Sur, San Cristóbal de las Casas.

Sánchez, J.E., D.C. Zied, E. Albertó, 2018. Edible mushroom production in the Americas. In: Tan, Q. (ed.), $9^{\text {th }}$ International Conference on Mushroom Biology and Mushroom Products. WSMBMP, Shanghai. Pp. 2-12.

Schwyn, B., J.B. Neilands, 1987. Universal chemical assay for the detection and determination of siderophores. Analytical Biochemistry 160: 47-56.

Singh, A.V., A. Sharma, B.N. Johri, 2012. Phylogenetic profiling of culturable bacteria associated with early phase of mushroom composting assessed by amplified rDNA restriction analysis. Annals of Microbiology 62: 675-682.

Singh, H., M.S. Reddy, 2011. Effect of inoculation with phosphate solubilizing fungus on growth and nutrient uptake of wheat and maize plants fertilized with rock phosphate in alkaline soils. European Journal of Soil Biology 47: 30-34.

Song, T.T., W.M. Cai, Q.L. Jin, W.L. Feng, L.J. Fan, Y.Y. Shen, F.F. Tian, 2014. Comparison of microbial communities and histological changes in Phase I rice straw-based Agaricus bisporus compost prepared using two composting methods. Scientia Horticulturae 174: 96-104.

Souza, T.P., S.C. Marques, D. Santos, E.S. Dias, 2014. Analysis of thermophilic fungal populations during phase II of composting for the cultivation of Agaricus subrufescens. World Journal of Microbiology and Biotechnology 30: 2419-2425.

Straatsma, G., J.P. Gerrits, T.M. Gerrits, H.J. Op den Camp, L.J. Van Griensven, 1991. Growth kinetics of Agaricus bisporus mycelium on solid substrate (mushroom compost). Microbiology 137: 1471-1477.

Straatsma, G., R.A. Samson, T.W. Olijnsma, H.J. Op den Camp, J.P. Gerrits, L.J. Van Griensven, 1994. Ecology of thermophilic fungi mushroom compost with emphasis on Scytalidium thermophilum and growth stimulation of Agaricus bisporus mycelium. Applied and Environmental Microbiology 60: 454-458.

Sundara, R., M. Sincha, 1963. Organism phosphate solubilizers in soil. Indian Jounal of Agriculture Science 33: 272-278.

Till, O., 1962. Champignonkultur auf sterilisiertem naehrsubstratum und die wiederverwendung von abgetragenem compost. Mushroom Science 5: 127-133.
Torres, E., J.E. Sanchez, G.K. Guillen, D.G. Ramos, D.J. Royse, 2016. Microbial promoters of mycelial growth, fruiting and production of Pleurotus ostreatus. Sydowia 68: 151-161.

Vajna, B., D. Szili, A. Nagy, K. Márialigeti, 2012. An improved sequence-aided T-RFLP analysis of bacterial succession during oyster mushroom substrate preparation. Microbial Ecology 64: 702-713.

Vargas, M.C., F. Suarez, M.J. López, J. Moreno, 2007. In vitro studies on lignocellulose degradation by microbial strains isolated from composting processes. International Biodeterioration and Biodegradation 59: 322-328.

Velázquez-Cedeño, M., A.M. Farnet; G. Mata, J.M. Savoie, 2008. Role of Bacillus spp. in antagonism between Pleurotus ostreatus and Trichoderma harzianum in heat-treated wheat-straw substrates. Bioresource Technology 99: 6966-6973.

Vijay, B., A. Pathak, 2014. Exploitation of thermophilic fungi in compost production for white button mushroom (Agaricus bisporus) cultivation-a review. In: Proceedings of 8th International Conference on Mushroom Biology and Mushroom Products (Volume I and II). WSMBMP, New Delhi. Pp. 292-308.

Watabe, M., J.R. Rao, A.R. Murphy, J.E. Moore, 2003. Inhibition of Listeria ivanovii by Paenibacillus lentimorbus isolated from phase II mushroom compost. World Journal of Microbiology and Biotechnology 19: 875-877.

Weisburg, W.G., S.M. Barns, D.A. Pelletier, D.J. Lane, 1991. 16S ribosomal DNA amplification for phylogenetic study. Journal of Bacteriology 173: 697.

White, T.J., T. Bruns, S. Lee, J. Taylor, 1990. Amplification and direct sequencing of fungal ribosomal RNA genes for phylogenetics. In: Innis, M.A., D.H. Gelfand, J.J. Sninsky, T.J. White (eds.), PCR protocols: a guide to methods and applications. Academic Press, New York. Pp. 315-322.

Wood, D.A., 1984. Microbial processes in mushroom cultivation; a large scale solid substrate fermentation. Journal of Chemical Technology and Biotechnology 34: 232-240.

Zarenejad, F., B. Yakhchali, I. Rasooli, 2012. Evaluation of indigenous potent mushroom growth promoting bacteria (MGPB) on Agaricus bisporus production. World Journal of Microbiology and Biotechnology 28: 99-104.

Zhang, H.L., J.K. Wei, Q.H. Wang, R. Yang, X.J. Gao, Y.X. Sang, P.P. Cai1, G.Q. Zhang, Q.J. Chen, 2019. Lignocellulose utilization and bacterial communities of millet straw based mushroom (Agaricus bisporus) production. Scientific Reports 9: 1151.

Zhang, X., Y. Zhong, S. Yang, W. Zhang, M. Xu, A. Ma, W. Liu, 2014. Diversity and dynamics of the microbial community on decomposing wheat straw during mushroom compost production. Bioresource Technology 170: 183-195. 